\title{
A Comparative Study of Heavy Metal Concentration in Different Layers of Tannery Vicinity Soil and Near Agricultural Soil
}

\author{
Ashiqur Rahaman*, Jahan Sadia Afroze, Khairul Bashar, Md. Farhad Ali, Md. Razib Hosen \\ Institute of Leather Engineering and Technology, University of Dhaka, Dhaka, Bangladesh \\ Email: ^ashik.shomik@gmail.com
}

How to cite this paper: Rahaman, A., Afroze, J.S., Bashar, K., Ali, Md.F. and Hosen, Md.R. (2016) A Comparative Study of Heavy Metal Concentration in Different Layers of Tannery Vicinity Soil and Near Agricultural Soil. American Journal of Analytical Chemistry, 7, 880-889.

http://dx.doi.org/10.4236/ajac.2016.712075

Received: October 7, 2016

Accepted: December 9, 2016

Published: December 12, 2016

Copyright $\odot 2016$ by authors and Scientific Research Publishing Inc. This work is licensed under the Creative Commons Attribution International License (CC BY 4.0).

http://creativecommons.org/licenses/by/4.0/

(c) (†) Open Access

\begin{abstract}
This research was conducted to bring out the appropriate level of heavy metal contamination in soil at the site of Buriganga river bank near the Hazaribagh tannery area and the normal agricultural area to evaluate heavy metal contamination in soil due to untreated tannery effluents. AAS flame method was used to determine the concentration of Chromium (Cr), lead ( $\mathrm{Pb})$, Cadmium (Cd), Zinc ( $\mathrm{Zn}$ ) in several depths of the soil. Results showed that, the heavy metal concentration in soil at the site of Buriganga river bank in the tannery vicinity and normal agricultural area significantly varies, such as $\mathrm{Cr}$ varies $(561.71-31.23) \mathrm{mg} / \mathrm{kg}$, $\mathrm{Zn}$ varies $(158.23$ - 73.5), $\mathrm{Pb}$ varies $(70.58-24)$ and $\mathrm{Cd}$ varies $(2.25-0.71) \mathrm{mg} / \mathrm{kg}$ in the river bank as well as in the normal agricultural area $\mathrm{Cr}$ varies $(27.869$ - 24.5416) $\mathrm{mg} / \mathrm{kg}$, $\mathrm{Zn}$ varies (134.167 $28), \mathrm{Pb}$ varies $(25.76-22.49)$ and Cd varies $(1.30-0.64) \mathrm{mg} / \mathrm{kg}$. The study indicated that heavy metals concentration was found to be significantly higher in river bank soils than in the normal agricultural area. This metal concentration in soil is responsible for the promotion of toxicity in agricultural products. Therefore, the human health and environment are affected by these areas.
\end{abstract}

\section{Keywords}

Heavy Metal, Soil, Contamination, Tannery Area, Agricultural Area

\section{Introduction}

In recent years, environment and health related problem by heavy metal has become a major concern [1]. As soil is a crucial component of rural and urban environments, the role of heavy metals in the soil system is increasingly becoming an issue of global concern [2]. The pollution of heavy metals in soil undesirably affects its physicochemical 
criteria important to infertility and low yield of crops due to their toxicity [3]. Nowadays, with the development of the global economy, soil contamination by heavy metal has gradually increased, resulting in the deterioration of the environment [4]. This soil is tainted by heavy metals through the irrigation system; resulting toxicity is entering into the food chain which affects the food quality and safety [5]. Contamination of soil by heavy metal due to tannery waste becomes a worldwide problem [6]. Wastewater from tanneries, industries or other sources carries a large amount of toxic heavy metals such as $\mathrm{Ca}, \mathrm{Fe}, \mathrm{Mg}, \mathrm{Na}, \mathrm{Ni}, \mathrm{Cr}, \mathrm{Cd}, \mathrm{Pb}, \mathrm{Zn}$ etc. which are responsible for the contamination of agricultural soil [7].

In Bangladesh, Tannery is an important foreign currency sector. There are 214 tanneries in Bangladesh and among them, 200 are located in Hazaribagh near the bank of Buriganga river, covering an area of $25 \mathrm{ha}$ and the rest of them are located many other districts [8]. The tanneries in Hazaribagh are posing a grave threat to the environment. During tanning operation, many chemicals such as $\mathrm{NaCl}, \mathrm{H}_{2} \mathrm{SO}_{4}, \mathrm{Ca}(\mathrm{OH})_{2}, \mathrm{Cr}\left(\mathrm{SO}_{4}\right)_{3}$, dyes are extensively used in which the leather takes only $50 \%-60 \%$ of the applied chemical and rest of them discharge as effluents [9]. Most of the tanneries in Hazaribagh do not have effluent treatment facilities. These tanneries dispose of their untreated effluent directly to open drain which finally connect to Buriganga River and discharge about $12,000 \mathrm{~m}^{3} \cdot \mathrm{d}^{-1}$ untreated effluents [10]. Some researchers demonstrated that during peak period about $14,910 \mathrm{~m}^{3} \cdot \mathrm{d}^{-1}$, off-peak period about $9100 \mathrm{~m}^{3} \cdot \mathrm{d}^{-1}$ effluent discharge from tanneries [8]. Consequently, distribution of heavy metals has taken from the untreated effluent to rivers, soil, water and crops [11].

Heavy metal in soils may go into the body directly through ingestion, skin contact etc. Heavy Metals in agricultural soils are absorbed and accumulated by crops. Ingesting heavy metals by soil-crop system is a major way of damaging human health [12].

The aim of this research was the assessment of heavy metals (Cr, Pd, Zn, Cd) in tannery effluent-affected land and compared the results with the concentration of heavy metals in unaffected soil.

\section{Materials and Methods}

\subsection{Study Area}

The soil samples (Figure 1) were collected from five different points of different sites in the vicinity of Hazaribagh tannery on the bank of the river Buriganga and Karigang agricultural area, Dhaka. Hazaribagh is a densely populated area of Dhaka city where about more than 200 registered tanneries discharge their huge amount of untreated solid and liquid waste directly into the Buriganga River. Karigang is also located in Dhaka where there are no such harmful industries near this area. So this area was chosen as a study area to compare the level of heavy metals with Hazaribagh area. Five different points in the tannery vicinity were marked as Point- 1 which is the dumping point itself, and Point-2, Point-3, Point-4, Point-5 which are located at $250 \mathrm{~m}, 500 \mathrm{~m}$, $1000 \mathrm{~m}$ and $2000 \mathrm{~m}$ distance respectively from the dumping point. Karigang agricultural area was marked as Point-6. 


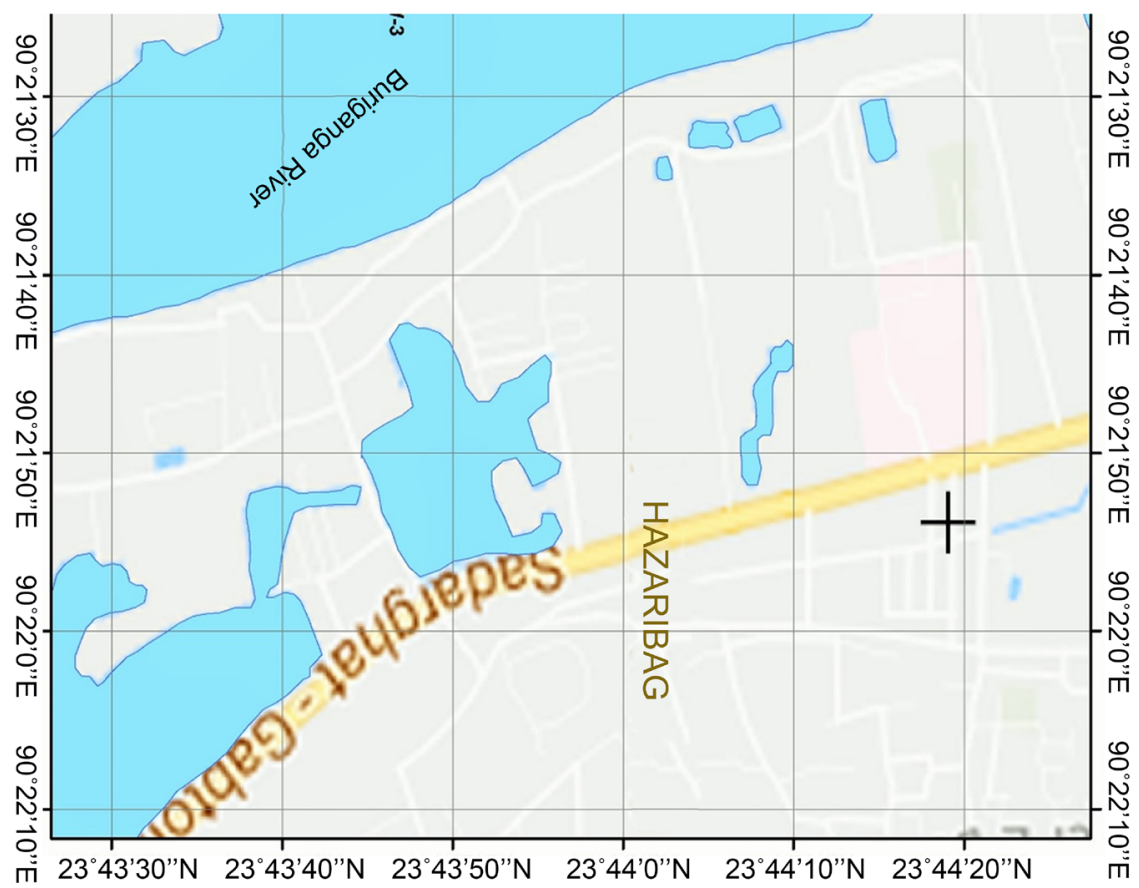

Figure 1. A real view of the sampling area with marked sample point.

\subsection{Sampling}

In the month of April 2016, the soil samples were collected from the sampling sites with the help of a stainless steel Ekman Grab Sampler and transferred to a pre-cleaned plastic container. The samples were collected from three different layers of different depth at each point. The first layer is the surface layer $(0-15 \mathrm{~cm})$ and the others are $15-30$ $\mathrm{cm}$ and $30-45 \mathrm{~cm}$ below from the surface level. After collecting the soil samples were washed, weighed and dried in an oven at $105^{\circ} \mathrm{C}$ until acquiring constant weight. After cooling in a desiccator all the samples were grounded and thoroughly homogenized by agate mortar and pastel. The powdered soil samples were finally stored in pre-cleaned dry glass bottles and preserved in a desiccator for further analysis.

\subsection{Digestion of Soil Sample}

For the quantitative analysis of $\mathrm{Cr}, \mathrm{Pb}, \mathrm{Cd}$ and $\mathrm{Zn}$ soil samples were digested following ISO 11466 thermal heating method. At the first $3 \mathrm{~g}$ of each grounded samples were weighed and taken into beakers. Then the weighed samples were moistened with $1 \mathrm{ml}$ distilled water. After that $21 \mathrm{ml}, \mathrm{HCl}$ and $7 \mathrm{ml} \mathrm{HNO}_{3}$ were added drop by drop and then $15 \mathrm{ml}$ of dilute $\mathrm{HNO}_{3}(0.5 \mathrm{M})$ was added to each beaker and the samples were allowed to stand at room temperature. Each mixture was then refluxed on a heating plate for two hours and was filtered through filter paper (Whitman no 40) after cooling and kept at room temperature for further determination

\subsection{Total Heavy Metals Concentration Measurement}

After digestion, the samples were taken to the Centre for Advanced Research and 
Science (CARS), the University of Dhaka for the subsequent analysis for metals $\mathrm{Cr}, \mathrm{Pb}$, $\mathrm{Cd}$ and $\mathrm{Zn}$ with a Perkin-Elmer atomic absorption spectrometer (Model-An Analyst 800, USA). Cd (Wavelength $228.8 \mathrm{~nm}$ ), Cr (Wavelength $357.9 \mathrm{~nm}$ ), $\mathrm{Pb}$ (Wavelength $283.3 \mathrm{~nm}$ ), and $\mathrm{Zn}$ (Wavelength $213.9 \mathrm{~nm}$ ) specific hollow cathode lamp was used to analyze the samples. The instrument has a minimum detection limit of $0.01 \mathrm{mg} / \mathrm{L}$ for $\mathrm{Cd}, 0.10 \mathrm{mg} / \mathrm{L}$ for $\mathrm{Cr}, 0.20 \mathrm{mg} / \mathrm{L}$ for $\mathrm{Pb}$ and $0.01 \mathrm{mg} / \mathrm{L}$ for $\mathrm{Zn}$ in the flame method. Samples were aspirated through nebulizer and absorbance was measured with a blank as reference. Calibration curve was obtained using standard samples (containing 0.2, 0.4, 0.6, 0.8 and $1.0 \mathrm{mg} / \mathrm{L}$ for Cd; 0.2, 0.5, 1.0, 2.0 and $4.0 \mathrm{mg} / \mathrm{L}$ for Cr; 0.5, 1.0, 2.0, 4.0 and $8.0 \mathrm{mg} / \mathrm{L}$ for $\mathrm{Pb}$ and $0.2,0.4,0.6,0.8,1.0$ and $2.0 \mathrm{mg} / \mathrm{L}$ for $\mathrm{Zn}$ ). The correlation coefficient was found for $\mathrm{Cd} 0.999, \mathrm{Cr} 0.994, \mathrm{~Pb} 0.999$ and for $\mathrm{Zn} 0.999$.

\section{Result and Discussion}

From the investigation, it was found that $\mathrm{Cr}$ concentrations of soils in the vicinity of Hazaribagh tannery are rather high and in the most cases, these exceeded the maximum permissible limits. The result recorded highest values of heavy metal content at the dumping point and lowest values in the soil of Agricultural area. The heavy metal content was found most abundantly in the surface layers and the values decreased with the increase of depth and distance except a few exceptions.

According to the (Figure 2) it is noticed that in the case of Tannery vicinity soil, $\mathrm{Cr}$ content was found most abundant $(561.71 \mathrm{mg} / \mathrm{kg})$ in the surface layer of point 1 (dumping point) and least abundant $(31.23 \mathrm{mg} / \mathrm{kg})$ in $30-45 \mathrm{~cm}$ depth of point 5 . In surface layer, values for $\mathrm{Cr}$ content ranged from 561.71 to $170.83 \mathrm{mg} / \mathrm{kg}$, in $15-30 \mathrm{~cm}$ depth, it ranged from 220.89 to $34.2 \mathrm{mg} / \mathrm{kg}$ and in $30-45 \mathrm{~cm}$ depth the range was from 90.09 to $28.72 \mathrm{mg} / \mathrm{kg}$ (Table 1). While in the case of Agricultural area soil, Cr content in surface layer, 15 - $30 \mathrm{~cm}$ and $30-45 \mathrm{~cm}$ depth is found 27.867, 26.0416 and 24.54166 $\mathrm{mg} / \mathrm{kg}$ respectively (Table 2 ).

From the result, it is evident that $\mathrm{Cr}$ content in the Tannery vicinity of similar layer decreased with the increase of distant from the dumping point and also with the increase of depth at each point except few exceptions. In the surface layer, the rate of decreasing with distance was much higher than two other layers. In comparison with the

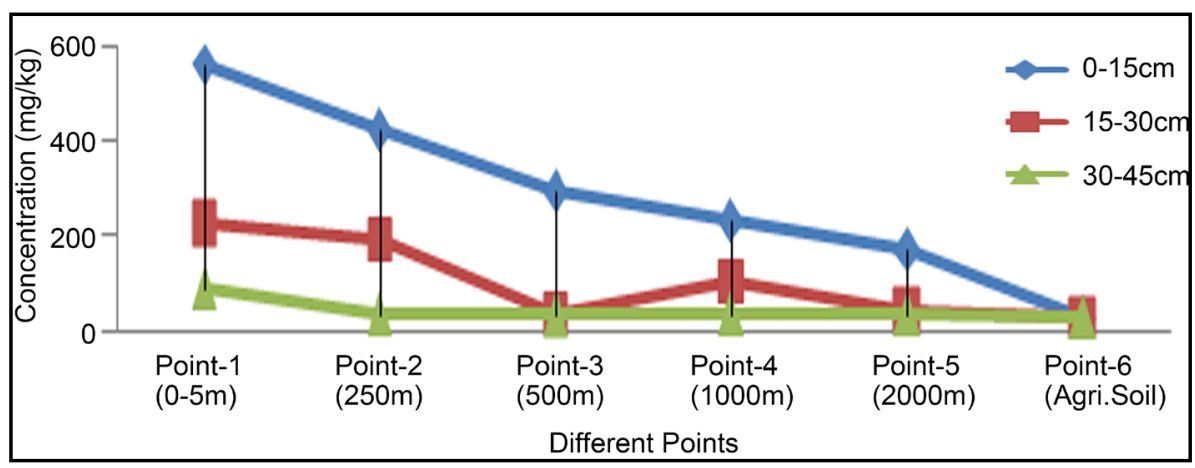

Figure 2. Concentration of $\mathrm{Cr}$ in Soil samples of different distance and depth. 
Table 1. Heavy metal content in tannery area soil.

\begin{tabular}{|c|c|c|c|c|c|}
\hline Sampling Points & $\begin{array}{l}\text { Depth of layers from } \\
\text { the surface level }(\mathrm{cm})\end{array}$ & $\begin{array}{c}\mathrm{Cr} \\
(\mathrm{mg} / \mathrm{kg})\end{array}$ & $\begin{array}{c}\mathrm{Pb} \\
(\mathrm{mg} / \mathrm{kg})\end{array}$ & $\begin{array}{c}\mathrm{Cd} \\
(\mathrm{mg} / \mathrm{kg})\end{array}$ & $\begin{array}{c}\mathrm{Zn} \\
(\mathrm{mg} / \mathrm{kg}\end{array}$ \\
\hline \multirow[t]{3}{*}{ Point-1 } & $0-15$ & 561.71 & 70.58 & 2.25 & 158.23 \\
\hline & $15-30$ & 220.89 & 42.95 & 1.28 & 118.52 \\
\hline & $30-45$ & 90.09 & 26.61 & 0.88 & 98.73 \\
\hline \multirow[t]{3}{*}{ Point-2 } & $0-15$ & 423.43 & 65.21 & 2.01 & 137.31 \\
\hline & $15-30$ & 191.73 & 38.90 & 1.26 & 107.65 \\
\hline & $30-45$ & 33.25 & 26.29 & 0.98 & 101.48 \\
\hline \multirow[t]{3}{*}{ Point-3 } & $0-15$ & 290.67 & 31.09 & 1.12 & 73.5 \\
\hline & $15-30$ & 34.20 & 26.31 & 0.898 & 121.33 \\
\hline & $30-45$ & 28.72 & 26.50 & 0.7660 & 107.33 \\
\hline \multirow[t]{3}{*}{ Point-4 } & $0-15$ & 230.15 & 30.73 & 1.01 & 107.23 \\
\hline & $15-30$ & 98.88 & 27.29 & 0.97 & 115.66 \\
\hline & $30-45$ & 33.33 & 24.37 & 0.81 & 103.15 \\
\hline \multirow[t]{3}{*}{ Point-5 } & $0-15$ & 170.83 & 27.97 & 0.93 & 123.72 \\
\hline & $15-30$ & 35.63 & 26.44 & 0.80 & 129.25 \\
\hline & $30-45$ & 31.23 & 28.29 & 0.71 & 115.88 \\
\hline $\begin{array}{l}\text { Maximum permissible limit } \\
\text { recommended by EC (1986) [13] }\end{array}$ & & $\begin{array}{c}50 \\
\mathrm{mg} / \mathrm{kg}\end{array}$ & $\begin{array}{c}300 \\
\mathrm{mg} / \mathrm{kg}\end{array}$ & $\begin{array}{c}3 \\
\mathrm{mg} / \mathrm{kg}\end{array}$ & - \\
\hline
\end{tabular}

Table 2. Heavy metal content in agricultural area soil.

\begin{tabular}{cccccc}
\hline Sampling Points & $\begin{array}{c}\text { Depth of layers from } \\
\text { the surface level }(\mathrm{cm})\end{array}$ & $\begin{array}{c}\mathrm{Cr} \\
(\mathrm{mg} / \mathrm{kg})\end{array}$ & $\begin{array}{c}\mathrm{Pb} \\
(\mathrm{mg} / \mathrm{kg})\end{array}$ & $\begin{array}{c}\mathrm{Cd} \\
(\mathrm{mg} / \mathrm{kg})\end{array}$ & $\begin{array}{c}\mathrm{Zn} \\
(\mathrm{mg} / \mathrm{kg})\end{array}$ \\
\hline & $0-15$ & 27.867 & 23.60 & 0.64 & 28 \\
Soil of agricultural area & $15-30$ & 26.0416 & 25.76 & 0.82 & 134.167 \\
& $30-45$ & 24.54166 & 22.49 & 1.30 & 80.5 \\
Maximum permissible limit & & 50 & 300 & 3 & - \\
recommended by EC (1986) [13] & & $\mathrm{mg} / \mathrm{kg}$ & $\mathrm{mg} / \mathrm{kg}$ & $\mathrm{mg} / \mathrm{kg}$ & \\
\hline
\end{tabular}

Agricultural area soil, in every case $\mathrm{Cr}$ concentration in the tannery vicinity soil is found higher than that of the agricultural area. In Tannery vicinity, in the surface layer of each point, the value of $\mathrm{Cr}$ content exceeded the permissible limit that is $50 \mathrm{mg} / \mathrm{kg}$ recommended by EC (1986) [13]. But Agricultural Area soil did not exceed that limit.

The high content of $\mathrm{Cr}$ in the surface layer of tannery vicinity soil may be due to pollution from various industrial wastes such as $\mathrm{Cr}$ pigment and untreated tannery wastes, electroplating sludge, leather manufacturing wastes, and municipal sewage sludge etc. [7].

$\mathrm{Cr}$ contamination in the soils could also be due to waste consisting of $\mathrm{Pb}$-Cr batteries, colored polythene bags, discarded plastic materials and empty paint containers [14]. 
$\mathrm{Cr}$ is toxic and carcinogenic and long-term exposure to $\mathrm{Cr}$ can cause liver and kidney damage [15].

$\mathrm{Cr}$ can also alter genetic materials and cause cancer. Other health problems that area used by $\mathrm{Cr}$ are Skin rashes, Upset stomachs, and ulcers, Respiratory problems, weakened immune systems, Alteration of genetic material, Lung cancer and Death [16].

$\mathrm{Pb}$ is the second prevalent element in this study. In the case of Tannery vicinity, $\mathrm{Pb}$ content was found most abundant $(70.58 \mathrm{mg} / \mathrm{kg}$ ) in the surface layer of point 1 (dumping point) and least abundant $(24.37 \mathrm{mg} / \mathrm{kg})$ in $30-45 \mathrm{~cm}$ depth of point 4 . In surface layer, values for $\mathrm{Pb}$ content ranged from 70.58 to $27.97 \mathrm{mg} / \mathrm{kg}$, in $15-30 \mathrm{~cm} \mathrm{depth}$, it ranged from 42.95 to $26.31 \mathrm{mg} / \mathrm{kg}$ and in $30-45 \mathrm{~cm}$ depth the range was from 28.29 to $24.37 \mathrm{mg} / \mathrm{kg}$. While in the case of Agricultural area soil, $\mathrm{Pb}$ content in the surface layer, $15-30 \mathrm{~cm}$ and $30-45 \mathrm{~cm}$ depth was found 27.87, 26.04 and $24.54 \mathrm{mg} / \mathrm{kg}$ respectively (Figure 3).

Also for $\mathrm{Pb}$ content in the Tannery vicinity soil of similar layer, the values decreased with the increase of distance from the dumping point and also with the increase of depth at each point except few exceptions. In the surface layer, the rate of decreasing with distance was much higher than two other layers. While it is compared with the Agricultural area soil, in every layer Pd concentration in the tannery vicinity soil is found higher than that of the agricultural area except $30-45 \mathrm{~cm}$ depth of point 4 which has value $(24.37 \mathrm{mg} / \mathrm{kg})$ higher than Agricultural Area soil $(24.54 \mathrm{mg} / \mathrm{kg})$ of the same layer. Neither Tannery vicinity soil nor Agricultural Area soil at any layer in this study exceeded the permissible limit for $\mathrm{Pb}$ that is $300 \mathrm{mg} / \mathrm{kg}$ recommended by EC (1986) [13].

The high content of $\mathrm{Pb}$ content near the dumping point may be due to the discharge of $\mathrm{Pb}$-containing untreated tannery effluent.

The presence of $\mathrm{Pb}$ in soil may also due to the release of $\mathrm{Pb}$ by automobiles and other industries in the area. This $\mathrm{Pb}$ can be deposited on soil and water, thus reaching humans via the food chain [17].

$\mathrm{Pb}$ in the soils could also be from automobile exhaust fumes as well as dry cell batteries, sewage effluents, runoff of wastes and atmospheric depositions [18].

$\mathrm{Pb}$ exposure has effects like disruption of the biosynthesis of hemoglobin and anemia, increase in blood pressure, Kidney damage, Miscarriages and subtle abortions,

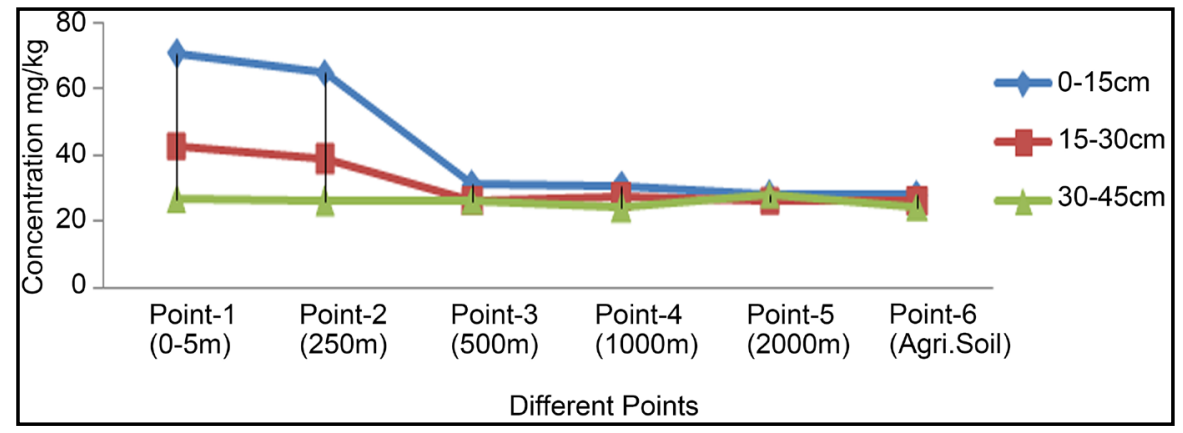

Figure 3. Concentration of $\mathrm{Pb}$ in soil samples of different distance and depth. 
Disruption of nervous methods, Brain injury, Declined fertility of men through sperm harm, Reduced education abilities of children, Behavioral disruptions of children, such as aggression, imprudent behavior and hyperactivity [16].

When Cd was taken into consideration, the content was found most abundant (2.25 $\mathrm{mg} / \mathrm{kg}$ ) in the surface layer of point 1 (dumping point) and least abundant $(0.71 \mathrm{mg} / \mathrm{kg}$ ) in $30-45 \mathrm{~cm}$ depth of point 5 in case of Tannery vicinity. In surface layer, values for $\mathrm{Cd}$ content ranged from 2.25 to $0.93 \mathrm{mg} / \mathrm{kg}$, in $15-30 \mathrm{~cm}$ depth it ranged from 1.28 to 0.8 $\mathrm{mg} / \mathrm{kg}$ and in $30-45 \mathrm{~cm}$ depth the range was from 0.98 to $0.71 \mathrm{mg} / \mathrm{kg}$. While in the case of Agricultural area soil, Cd content in surface layer, $15-30 \mathrm{~cm}$ and $30-45 \mathrm{~cm}$ depth is found $0.64,0.82$ and $1.3 \mathrm{mg} / \mathrm{kg}$ respectively (Figure 4).

At Point-3, Point-4 and Point-5, the concentration of Cd was more or less similar. In surface layer and $25-30 \mathrm{~cm}$ depth of tannery vicinity soil concentration of Cd decreased with the increase of distance from the dumping point. The result was not similar when $30-45 \mathrm{~cm}$ depth was considered as such regularity in the values was not found there. Like $\mathrm{Cr}$ and $\mathrm{Pb}$, the concentration of $\mathrm{Cd}$ also decreased with the increase of depth at each point in the tannery vicinity. But this was not the case for Agricultural area soil as the result was opposite there.

For surface layer, Cd content in each point of the Tannery vicinity was found higher than that of Agricultural area. Same was the case for $15-30 \mathrm{~cm}$ depth except in Point-5 that has a value $(0.80 \mathrm{mg} / \mathrm{kg})$ than that of Agricultural area soil $(0.82 \mathrm{mg} / \mathrm{kg})$. But unlike $\mathrm{Cr}$ and $\mathrm{Pb}, \mathrm{Cd}$ content in $30-45 \mathrm{~cm}$ depth of Agricultural area soil was found higher than that of each point in the Tannery vicinity soil.

At any layer of any point in both Tannery vicinity soil and Agricultural area soil, $\mathrm{Cd}$ content did not exceed the maximum permissible limit $(3.0 \mathrm{mg} / \mathrm{kg})$ recommended by EC (1986) [13].

The $\mathrm{Cd}$ is brought to soils with the application of phosphoric fertilizers. Application of a lot of phosphate fertilizers and compound fertilizers increases $\mathrm{Cd}$ in soils constantly [4].

Other sources of $\mathrm{Cd}$ could be paint, plastics, ceramics and glass manufacture industry [7].

The Cd is highly poisonous and even at very little concentrations, chronic exposure to this metal can prime to anemia, insomnia, cardiovascular diseases as well as hypertension [19].

Similarly for $\mathrm{Zn}$, In the case of Tannery vicinity, the metal content was found most abundant $(158.23 \mathrm{mg} / \mathrm{kg})$ in the surface layer of point 1 (dumping point) and least abundant $(73.5 \mathrm{mg} / \mathrm{kg})$ in the surface layer of point 3 . In surface layer, values of $\mathrm{Zn}$ content varied from 158.23 to $73.5 \mathrm{mg} / \mathrm{kg}$, in $15-30 \mathrm{~cm}$ depth it varied from 129.25 to $107.65 \mathrm{mg} / \mathrm{kg}$ and in $30-45 \mathrm{~cm}$ depth the range was from 115.88 to $98.73 \mathrm{mg} / \mathrm{kg}$. While in the case of Agricultural area soil, Zn content in the surface layer, $15-30 \mathrm{~cm}$ and 30 $45 \mathrm{~cm}$ depth was found 28.0, 134.17 and $80.5 \mathrm{mg} / \mathrm{kg}$ respectively (Figure 5).

Like $\mathrm{Cr}$ and $\mathrm{Pb}, \mathrm{Zn}$ does not show regularity in results. In point 4 and Point 5 , no significant variations in values were noticed. In Tannery vicinity soil, $\mathrm{Zn}$ records lowest value $(73.5 \mathrm{mg} / \mathrm{kg})$ at Point 3 in the case of the surface layer and the value 


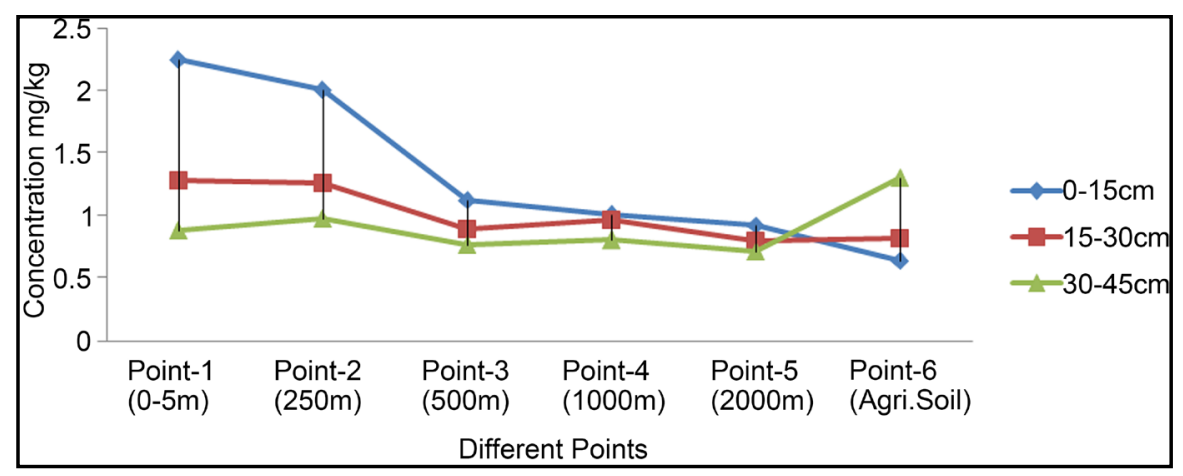

Figure 4. Concentration of Cd in Soil samples of different distance and depth.

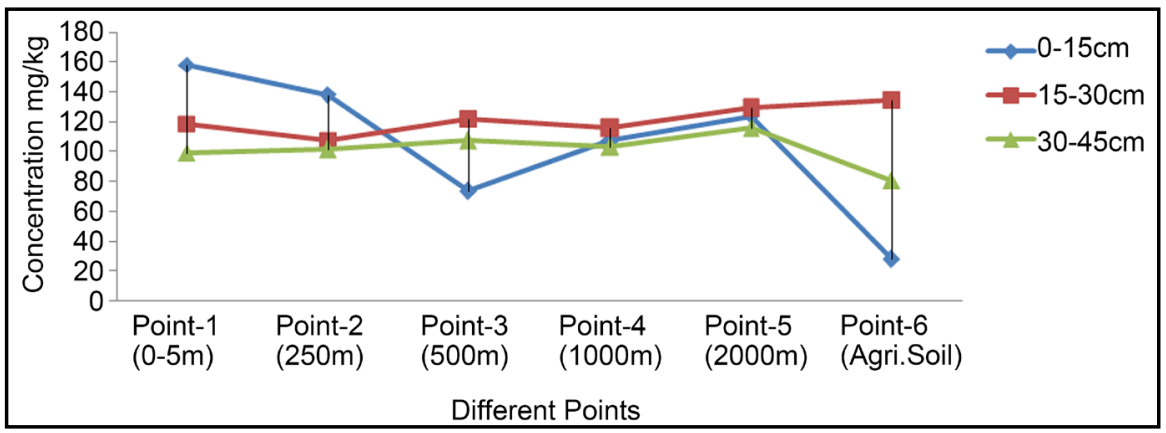

Figure 5. Concentration of $\mathrm{Zn}$ in Soil samples of different distance and Depth.

increases towards the dumping point as well as away from the dumping point. Whereas in $15-30 \mathrm{~cm}$ and $30-45 \mathrm{~cm}$ depth values of $\mathrm{Cr}$ content are irregular.

It is also noticed that in the case of the surface layer and $30-45 \mathrm{~cm}$ depth, Agricultural Area soil has lower $\mathrm{Zn}$ content Tannery vicinity soil at each point. But the result is opposite for 15 - $30 \mathrm{~cm}$ depth as Agricultural Area soil shows higher Zn content than that of Tannery vicinity soil.

The main sources of $\mathrm{Zn}$ contamination are industries as well as the use of liquid manure, composted materials and agrochemicals like fertilizers as well as pesticides in agriculture [6].

$\mathrm{Zn}$ is an essential trace element for the growth of humans, animals and plants but is potentially dangerous for the biosphere when present in high concentrations [18]. High doses of $\mathrm{Zn}$ show poisonous and carcinogenic effects and consequence in neurologic as well as hematological complications, hypertension, and kidney and liver function disorders [20].

\section{Conclusion}

Heavy Metal pollution in soil has now become a major concern. In a developing country like Bangladesh, the situation is worst due to lacking of technological advancement. From this study, it is clearly the evident that the soil in the tannery vicinity on the bank of river Buriganga is highly contaminated with Cr. This is due to being exposed to a huge amount of untreated tannery effluents and sludge from the nearby Hazaribagh 
Tannery industries every day. A significant amount of $\mathrm{Pb}, \mathrm{Cd}$ and $\mathrm{Zn}$ has also been found in the soil of this area. These heavy metals are deposited and accumulated in soil and uptake by vegetables and other foodstuffs grown in this area which ultimately get into human body through the food chain. This results in various adverse effect on human and animal health as $\mathrm{Cr}, \mathrm{Pb}$ and $\mathrm{Cd}$ are highly toxic and carcinogenic in nature. So authority concerned should take immediate actions in this matter to prevent such pollution by heavy metals.

\section{References}

[1] Latif, S.A., Hossain, S.M., Uddin, M.S., Hafiz, M.A., Islam, M.A. and Mubin, M.S.H. (2008) Studies on Environmental Pollution in Bangladesh Using Reactor Based Neutron Activation Analysis Technique. International Conference on Research Reactors. Safe Management and Effective Utilization, Citeseer.

[2] del Mar López, T., Aide, T.M. and Thomlinson, J.R. (2001) Urban Expansion and the Loss of Prime Agricultural Lands in Puerto Rico. AMBIO: A Journal of the Human Environment, 30, 49-54. https://doi.org/10.1579/0044-7447-30.1.49

[3] Khan, M.S., Zaidi, A., Wani, P.A. and Oves, M. (2009) Role of Plant Growth Promoting Rhizobacteria in the Remediation of Metal Contaminated Soils. Environmental Chemistry Letters, 7, 1-19. https://doi.org/10.1007/s10311-008-0155-0

[4] Su, C., Jiang, L. and Zhang, W. (2014) A Review on Heavy Metal Contamination in the Soil Worldwide: Situation, Impact and Remediation Techniques. Environmental Skeptics and Critics, 3, 24-38.

[5] Muchuweti, M., Birkett, J.W., Chinyanga, E., Zvauya, R., Scrimshaw, M.D. and Lester, J.N. (2006) Heavy Metal Content of Vegetables Irrigated with Mixtures of Wastewater and Sewage Sludge in Zimbabwe: Implications for Human Health. Agriculture, Ecosystems \& Environment, 112, 41-48. https://doi.org/10.1016/j.agee.2005.04.028

[6] Gowd, S.S., Reddy, M.R. and Govil, P. (2010) Assessment of Heavy Metal Contamination in Soils at Jajmau (Kanpur) and Unnao Industrial Areas of the Ganga Plain, Uttar Pradesh, India. Journal of Hazardous Materials, 174, 113-121. https://doi.org/10.1016/j.jhazmat.2009.09.024

[7] Rahman, S.H., Khanam, D., Adyel, T.M., Islam, M.S., Ahsan, M.A. and Akbor, M.A. (2012) Assessment of Heavy Metal Contamination of Agricultural Soil around Dhaka Export Processing Zone (DEPZ), Bangladesh: Implication of Seasonal Variation and Indices. $A p$ plied Sciences, 2, 584-601. https://doi.org/10.3390/app2030584

[8] Huq, S.I. (1998) Critical Environmental Issues Relating to Tanning Industries in Bangladesh. Aciar Proceedings, Coimbatore, 31 January-4 February 1998.

[9] Afzal, M., Shabir, G., Iqbal, S., Mustafa, T., Khan, Q.M. and Khalid, Z.M. (2014) Assessment of Heavy Metal Contamination in Soil and Groundwater at Leather Industrial Area of Kasur, Pakistan. CLEAN-Soil, Air, Water, 42, 1133-1139. https://doi.org/10.1002/clen.201100715

[10] Chowdhury, M., Mostafa, M.G., Biswas, T.K. and Saha, A.K. (2013) Treatment of Leather Industrial Effluents by Filtration and Coagulation Processes. Water Resources and Industry, 3, 11-22. https://doi.org/10.1016/j.wri.2013.05.002

[11] Arora, M., Kiran, B., Rani, S., Rani, A., Kaur, B. and Mittal, N. (2008) Heavy Metal Accumulation in Vegetables Irrigated with Water from Different Sources. Food Chemistry, 111, 811-815. https://doi.org/10.1016/j.foodchem.2008.04.049 
[12] Aelion, C.M., Davis, H.T., McDermott, S. and Lawson, A.B. (2008) Metal Concentrations in Rural Topsoil in South Carolina: Potential for Human Health Impact. Science of the Total Environment, 402, 149-156. https://doi.org/10.1016/j.scitotenv.2008.04.043

[13] Council Directive (1986) Council Directive on the Protection of the Environment, and in Particular of the Soil, When Sewage Sludge Is Used in Agriculture. Offic. J. Eur. Comm, 181, 0006-0012.

[14] Jung, C., Matsuto, T. and Tanaka, N. (2006) Flow Analysis of Metals in a Municipal Solid Waste Management System. Waste Management, 26, 1337-1348. https://doi.org/10.1016/j.wasman.2005.11.018

[15] Mondol, M., Chamon, A.S., Faiz, B. and Elahi, S.F. (2011) Seasonal Variation of Heavy Metal Concentrations in Water and Plant Samples around Tejgaon Industrial Area of Bangladesh. Journal of Bangladesh Academy of Sciences, 35, 19-41. https://doi.org/10.3329/jbas.v35i1.7968

[16] Islam, S., Islam, F., Bakar, M.A., Das, S. and Bhuiyan, H.R. (2013) Heavy Metals Concentration at Different Tannery Wastewater Canal of Chittagong City in Bangladesh. International Journal of Agriculture, Environment and Biotechnology, 6, 355-362. https://doi.org/10.5958/j.2230-732X.6.3.003

[17] Järup, L. (2003) Hazards of Heavy Metal Contamination. British Medical Bulletin, 68, 167182. https://doi.org/10.1093/bmb/ldg032

[18] Adaikpoh, E.O. (2013) Distribution and Enrichment of Heavy Metals in Soils from Waste Dump Sites within Imoru and Environs, Southwest Nigeria.

[19] Sharma, R., Agrawal, M. and Marshall, F. (2006) Heavy Metal Contamination in Vegetables Grown in Wastewater Irrigated Areas of Varanasi, India. Bulletin of Environmental Contamination and Toxicology, 77, 312-318. https://doi.org/10.1007/s00128-006-1065-0

[20] Rao, M., Gopalkrishnan, R. and Venkatesh, B. (2001) Medical Geology-An Emerging Field in Environmental Science. National Symposium on Role of Earth Sciences, Lucknow, 2-4 November 2001.

\section{Submit or recommend next manuscript to SCIRP and we will provide best service for you:}

Accepting pre-submission inquiries through Email, Facebook, LinkedIn, Twitter, etc.

A wide selection of journals (inclusive of 9 subjects, more than 200 journals)

Providing 24-hour high-quality service

User-friendly online submission system

Fair and swift peer-review system

Efficient typesetting and proofreading procedure

Display of the result of downloads and visits, as well as the number of cited articles

Maximum dissemination of your research work

Submit your manuscript at: http://papersubmission.scirp.org/

Or contact ajac@scirp.org 